\title{
Effect of low-intensity pulsed ultrasound on 1929 fibroblasts
}

\author{
Rodrigo Franco de Oliveira', Deise A. A. Pires Oliveira ${ }^{1}$, Cristina Pacheco Soares ${ }^{2}$
}

${ }^{1}$ Centro de Pesquisa em Ciências da Saúde, Universidade Norte do Paraná - Unopar Londrina, PR, Brazil

2Laboratório de Dinâmica de Compartimento Celular, Instituto de Pesquisa e Desenvolvimento - IP\&D, Univap - São José dos Campos, SP, Brazil

Submitted: 9 October 2009

Accepted: 18 January 2010

Arch Med Sci 2011; 7, 2: 224-229

DOI: 10.5114/aoms.2011.22071

Copyright ( 2011 Termedia \& Banach

\section{Abstract}

Introduction: Ultrasound has proven to be an important therapeutic resource regarding musculoskeletal disease and is routinely used in physical therapy and medicine both therapeutically and diagnostically. The aim of the present study was to analyse the effects with different ultrasound intensities in order to establish the ideal radiation level in cell cultures.

Material and methods: Fibroblast cell cultures were divided into five groups: group I - control (did not receive irradiation); group II $-0.2 \mathrm{~W} / \mathrm{cm}^{2}$ in pulsed mode at $10 \%$ (1: 9 duty cycle); group $\mathrm{III}-0.6 \mathrm{~W} / \mathrm{cm}^{2}$ in pulsed mode at $10 \%$ ( $1: 9$ duty cycle); group IV $-0.2 \mathrm{~W} / \mathrm{cm}^{2}$ in pulsed mode at $20 \%$ ( $2: 8$ duty cycle); and group $\mathrm{V}-0.6 \mathrm{~W} / \mathrm{cm}^{2}$ in pulsed mode at $20 \%$ (2: 8 duty cycle). Each group was irradiated with 24 -h intervals, observing the following post-irradiation incubation times: 24, 48, 72 and 96 h; after 24 h of each irradiation, cultures were analysed using the MTT method.

Results: Analysis of the results following ultrasound irradiation demonstrated that the effect of ultrasound with $0.6 \mathrm{~W} / \mathrm{cm}^{2}$ in pulsed mode at $10 \%(1: 9$ duty cycle) was statistically significant in relation to ultrasonic irradiation in pulsed mode at 20\% ( $2: 8$ duty cycle) $(p<0.05)$.

Conclusions: According to parameters used in the irradiation of cultivated fibroblasts, the pulse mode regime and the control of intensity are of fundamental importance for the optimal use of therapeutic ultrasound. Furthermore, low and medium intensities decreased cell damage, which establishes that acoustic pulsed energy induces the proliferation of fibroblast cells.

Key words: low-intensity pulsed ultrasound, inflammation, healing, repair, fibroblasts.

\section{Introduction}

Ultrasound has proven to be an important therapeutic resource regarding musculoskeletal disease and is used both therapeutically as well as diagnostically in medicine. Ultrasound delivers energy through a pressure field generated by the transducer that causes the molecules in the transmission medium to oscillate or vibrate. Mechanical stimulation of cell membranes occurs during the energy delivery process [1].

Ultrasound was introduced into the biological field about 70 years ago and is now widely used. However, research continues to be carried out to explore its field of action and get a better understanding of its effects and interaction with the biological medium. Despite the various advances, the

\section{Corresponding author:}

Rodrigo Franco de Oliveira

Universidade Norte

do Paraná

Unopar - Centro de Pesquisa

em Ciências da Saúde

Londrina, PR, Brazil

Av. Paris 675

Cep 86041-120

E-mail:

rfrancoli@yahoo.com.br 
actual mechanisms of interaction between ultrasound/cavitation and cells remain far from being understood. Moreover, the manner in which ultrasound and cavitation augment cell membrane permeability is not yet clear. This is likely the result of a lack of methods for real-time monitoring of cavitation at the cell level [2].

Nonetheless, ultrasound is an indispensable tool for physical therapists and is commonly used to help in the treatment of soft tissue dysfunctions, including contractures, joint injuries, tendonitis, bursitis, musculoskeletal spasms and pain. It has good ability to penetrate tissue and can be focused into a small volume to give very high energy locally. This is an attractive characteristic from a clinical viewpoint, and has prompted extensive applications of low-intensity pulsed ultrasound (LIPUS) for therapeutic purposes in clinical practice. With regard to the physical effects produced by ultrasound, a significant response is obtained from biological tissues (thermal and mechanical) [3-5].

According to Milowska [6] and O'Brien Jr [7], mechanisms of action of ultrasound with biological means can be divided into thermal effects and nonthermal. Thermal acoustical effects occur when the energy is absorbed and transformed into heat; it depends on the absorption and dissipation of energy through the ultrasound. However, nonthermal effects cannot be classified as cavitational due to training and concentration of bubbles.

Ultrasonic irradiation leads to angiogenesis stimulation, increased blood circulation, and accelerated repair of fractures with the retardation of consolidation and pseudo-arthrosis [8, 9]. It also inhibits inflammatory activity, resulting in the production of chemical mediators that activate the proliferation of fibroblasts [10]. This activation leads to the early accumulation of endothelial cells in the tissue as well as the promotion of collagen synthesis through the stimulation of calcium influx and a change in membrane permeability, thereby favouring the synthesis and maturation of collagen as well as the formation of scar tissue. Moreover, collagen deposited following the application of therapeutic ultrasound is more resistant and better organized [11, 12].

Fibroblasts are the major cell type in connective tissue and are critical for tissue restoration and remodelling after injury [1, 13-15]. Thus, the aim of the present study was to analyse the effects with different ultrasound intensities in order to establish the ideal radiation level in cell cultures.

\section{Material and methods}

\section{Cell culture}

L929 fibroblast cells (Mouse conjunctive tissue - ATCC CCL-1 NCTC) (Instituto Adolfo Lutz - SP, Brazil) were routinely cultured in $25 \mathrm{~cm}^{2}$ flasks (TPP,
Switzerland, Europe) with MEM (Minimum Essential Medium) (Gibco ${ }^{T M}$ - Invitrogen Corporation, Grand Island, USA), supplemented with 10\% FBS (fetal bovine serum) (Cultilab, Brazil) and kept in a humidified $5 \% \mathrm{CO}_{2}$ atmosphere at $37^{\circ} \mathrm{C}$. The protocol was approved by the Research Ethics Committee of Univap, Protocol $n^{\circ}$ A061/CEP/2006. Conjunctive tissue of mouse cells was used in this experiment, since ISO 10993-5 recommends the use of this cell line for in vitro toxicity tests [16].

\section{Ultrasound}

Ultrasound $\mathrm{KLD}^{\circledR}$ - Biosistemas Equipamentos Eletrônicos Ltda, Brazil, model Avatar III, with one $1 \mathrm{MHz}$ transducer and an ERA (effective radiation area) of $1 \mathrm{~cm}^{2}$, duly calibrated by the manufacturer.

\section{Irradiation}

Before receiving ultrasonic irradiation, L929 cell cultures were sub-cultivated in four 12-well $100 \mathrm{~mm}^{2}$ TPP $^{\circledR}$ plates at a density of $1 \times 10^{6} \mathrm{cell} / \mathrm{ml}$ and separated into five groups: group I - control (did not receive irradiation); group $\mathrm{II}-0.2 \mathrm{~W} / \mathrm{cm}^{2}$ in pulsed mode at 10\% (1:9 duty cycle $-1 \mathrm{~ms}$ and $9 \mathrm{~ms}$ work interval); group III $-0.6 \mathrm{~W} / \mathrm{cm}^{2}$ in pulsed mode at $10 \%$ (1 : 9 duty cycle $-1 \mathrm{~ms}$ and 9 ms work interval); group IV $-0.2 \mathrm{~W} / \mathrm{cm}^{2}$ in pulsed mode at 20\% (2 : 8 duty cycle $-2 \mathrm{~ms}$ and $8 \mathrm{~ms}$ work interval); and group $\mathrm{V}-0.6 \mathrm{~W} / \mathrm{cm}^{2}$ in pulsed mode at $20 \%$ ( 2 : 8 duty cycle $-2 \mathrm{~ms}$ and $8 \mathrm{~ms}$ work interval). Each group was irradiated with $24-\mathrm{h}$ intervals, observing the following times of incubation after irradiation: 24 h, 48 h, 72 h and $96 \mathrm{~h} ; 24 \mathrm{~h}$ after each irradiation the cultures were analysed by the MTT method. For a good coupling of the ultrasound interface (transducer distance $18 \mathrm{~mm}$ from the cell culture, according to the manufacturer's specifications) and propagation of mechanical waves, well volumes were completed to the brim with MEM medium; the irradiated well was always kept in the same position in relation to the transducer face of the ultrasound; each well received a 2-min irradiation at room temperature and plate heating was disregarded. The experiment was carried out in triplicate.

\section{MTT cellular cytotoxicity test}

The cytotoxicity experiments evaluated cultures that received ultrasonic irradiation at intervals of $24 \mathrm{~h}, 48 \mathrm{~h}, 72 \mathrm{~h}$ and $96 \mathrm{~h}$ through the MTT method [3-(4.5-dimethylthiazol-2-yl)-2.5-diphenyltetrazolium bromide] [17]; the MTT test was carried out $24 \mathrm{~h}$ after each irradiation according to the following assay: after the MEM medium was removed, each well received $80 \mu \mathrm{l}$ of MTT to obtain a final concentration of $0.5 \mathrm{mg} / \mathrm{ml}$ and was incubated for $1 \mathrm{~h}$ at $37^{\circ} \mathrm{C}$ in a $5 \% \mathrm{CO}_{2}$ atmosphere. After this 


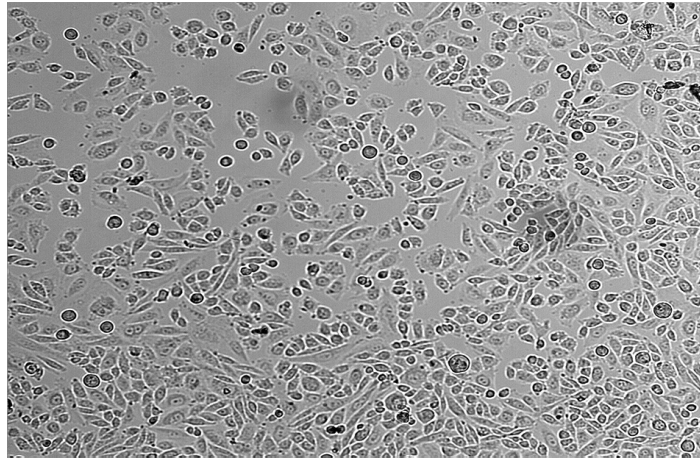

Figure 1. Cell cultures submitted to low-intensity ultrasound irradiation maintained shape and cell integrity

$400 \mu$ l of DMSO (dimethyl sulfoxide) were added to each well. The plate was kept in agitation for $30 \mathrm{~min}$ for solubilization of formazan crystals. The crystal concentration was spectroscopically quantified by means of a microplate reader (Reader ELISA - SpectraCount - Packard Instrument, USA) at a wavelength of $570 \mathrm{~nm}$.

\section{Statistical analysis}

Results are expressed as mean values \pm SEM. Comparisons between groups were made using one-way analysis of variance (ANOVA) and post hoc Tukey-HSD test. Analysis was used to determine significant differences between groups. Values of $p<0.05$ were considered statistically significant. Values were analysed using the GraphPad Prism 4.0 Demo statistical package.

\section{Results}

Analysis of results after LIPUS irradiation revealed that irradiated cells maintained their shape and cell integrity (Figure 1). The data demonstrate that $L 929$ cell cultures submitted to low-intensity ultrasonic irradiation $\left(0.2 \mathrm{~W} / \mathrm{cm}^{2}\right.$ to $\left.0.6 \mathrm{~W} / \mathrm{cm}^{2}\right)$ maintained cellular morphology, thereby corroborating the results described by Hsieh [18].

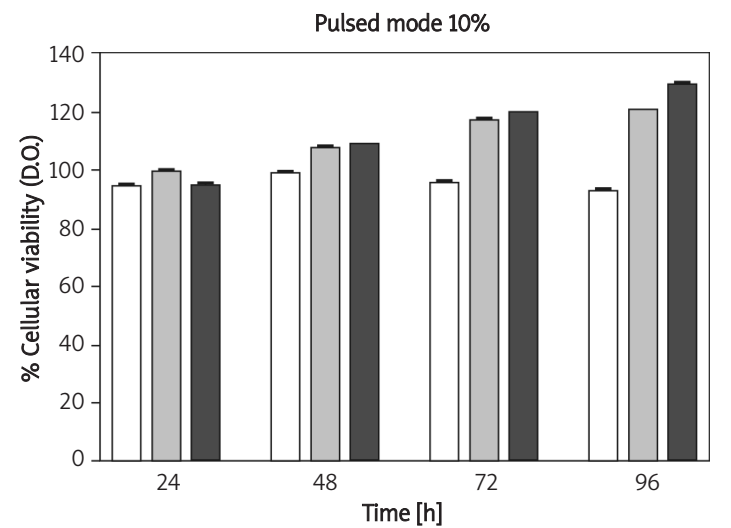

$\square$ Control $\square 0.2 \mathrm{~W} / \mathrm{cm}^{2} \quad \square 0.6 \mathrm{~W} / \mathrm{cm}^{2}$

Figure 2. Cellular growth due to ultrasonic irradiation and cultivation time; cellular viability of control populations

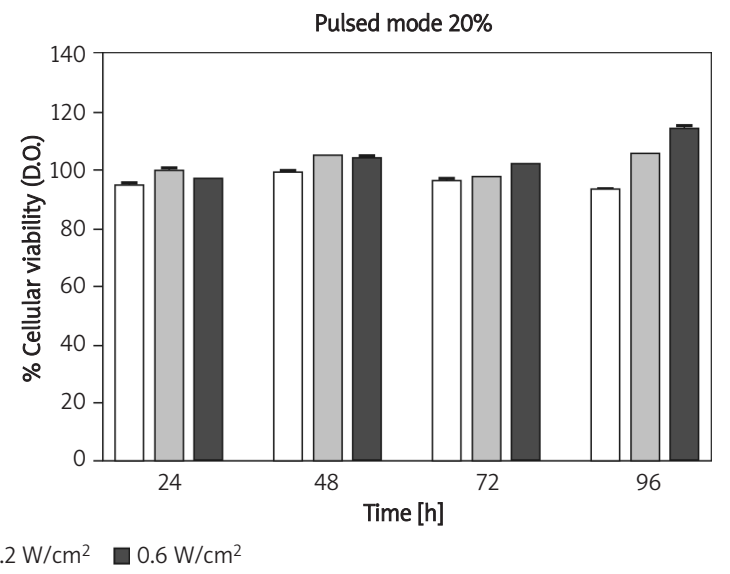

The results reveal that irradiation with MTT reflected the number of living cells in the culture. There were significant increases after analysing the effect of LIPUS at 10\% (1: 9 duty cycle) and $20 \%$ ( $2: 8$ duty cycle) on fibroblast culture (Figure 2).

The following results were obtained after analysing the effect of LIPUS at 10\% (1: 9 duty cycle) on fibroblast cultures. After $24 \mathrm{~h}$, the group of cells irradiated at an intensity of $0.2 \mathrm{~W} / \mathrm{cm}^{2}$ to $0.6 \mathrm{~W} / \mathrm{cm}^{2}$ exhibited increased cellular viability when compared with data for the group of nonirradiated cells $(p=0.001)$. However, when comparing the effect of irradiated cells at $0.2 \mathrm{~W} / \mathrm{cm}^{2}$ and $0.6 \mathrm{~W} / \mathrm{cm}^{2}$, the results did not show statistical significance $(p=0.06)$. After $48 \mathrm{~h}$, these groups of cells exhibited the same behaviour (non-irradiated and irradiated at $0.2 \mathrm{~W} / \mathrm{cm}^{2}$ and $\left.0.6 \mathrm{~W} / \mathrm{cm}^{2}\right)$ as during the first $24 \mathrm{~h}(p=0.001)$. Seventy-two $\mathrm{h}$ after irradiation, group II and group III irradiated cells exhibited a significant increase in cell viability when compared with viability values from the control group (non-irradiated) $(p=0.001)$. An interesting fact about this period of time was the significant increase in cell viability exhibited by cells irradiated at intensity of $0.6 \mathrm{~W} / \mathrm{cm}^{2}$ when compared with values for cells irradiated at $0.2 \mathrm{~W} / \mathrm{cm}^{2}$ $(p=0.01) 96 \mathrm{~h}$ after the first irradiation. The groups of cells irradiated at $0.2 \mathrm{~W} / \mathrm{cm}^{2}$ and $0.6 \mathrm{~W} / \mathrm{cm}^{2}$ tended to maintain their growth or pattern the same way as presented in the analysis $72 \mathrm{~h}$ after irradiation (Table I).

The following results were obtained after analysing LIPUS mode at 20\% ( $2: 8$ duty cycle). After $24 \mathrm{~h}$, irradiated group IV and group V cells exhibited an increase in cell viability when compared with data for the group of non-irradiated cells $(p=0.01)$. Cells irradiated at $0.2 \mathrm{~W} / \mathrm{cm}^{2}$ exhibited a significant increase in cell viability when compared with values for cells irradiated at $0.6 \mathrm{~W} / \mathrm{cm}^{2}(p=0.01)$. Forty-eight $\mathrm{h}$ after irradiation, cells maintained the same growth

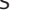


Table I. Significance values obtained from variance analysis of means of experiments by one-way ANOVA and Tukey's HSD post hoc test, for cells irradiated by ultrasound in pulsed mode at 10\% (1:9 duty cycle)

\begin{tabular}{|lccc|}
\hline Time $[\mathrm{h}]$ & Control vs. $0.2 \mathrm{~W} / \mathrm{cm}^{2}$ & Control vs. $0.6 \mathrm{~W} / \mathrm{cm}^{2}$ & $0.2 \mathrm{~W} / \mathrm{cm}^{2}$ vs. $0.6 \mathrm{~W} / \mathrm{cm}^{2}$ \\
\hline 24 & $0.001^{*}$ & $0.001^{*}$ & 0.06 \\
\hline 48 & $0.001^{*}$ & $0.001^{*}$ & 0.065 \\
\hline 72 & $0.001^{*}$ & $0.001^{*}$ & $0.01^{*}$ \\
\hline 96 & $0.001^{*}$ & $0.001^{*}$ & $0.01^{*}$ \\
\hline
\end{tabular}

${ }^{\star}$ For values with statistical significance

pattern. However, when comparing the effect between cells irradiated at $0.2 \mathrm{~W} / \mathrm{cm}^{2}$ and $0.6 \mathrm{~W} / \mathrm{cm}^{2}$, the results revealed no statistical significance $(p=0.08)$. In the 72 -h period, behaviour was constant, similar to the 48-h period after the first irradiation. However, it should be pointed out that there was a discrete tendency towards a decrease in cell growth values after $48 \mathrm{~h}$. After $96 \mathrm{~h}$, growth values for cells irradiated at $0.2 \mathrm{~W} / \mathrm{cm}^{2}$ and $0.6 \mathrm{~W} / \mathrm{cm}^{2}$ were significantly higher than those for non-irradiated cells (control) $(p=0.001)$. There was significantly higher cell growth among cells irradiated at $0.6 \mathrm{~W} / \mathrm{cm}^{2}$ than cells irradiated at $0.2 \mathrm{~W} / \mathrm{cm}^{2}$ (Table II).

\section{Discussion}

Ter Haar [19] observed that pulsed ultrasound may alter the cell structure and functioning. This is due to its transient cavitation effect as well as a change in volume and pressure caused by bubbles formed in the liquid medium, which when hitting one another release energy that may break chemical bonds, thereby producing reactive free radicals and provoking chemical changes in the cells. A change in pressure exerted by bubbles may modify the permeability of the cellular membrane to calcium and sodium ions, increasing protein synthesis. Furthermore, organelles may be altered due to irradiation forces.

A number of research groups have shown that bubbles under LIPUS scanning conditions increase the permeability of the cell membrane to external substances and enhance their uptake in the cavitation process [2]. According to Kodama et al. [20] the viability of cells is different at each position. This would appear to indicate that fluid motion is involved in cell membrane damage and subsequent molecular delivery.

Zhou et al. [13] showed that a single lowintensity pulsed treatment is able to promote DNA synthesis in fibroblast cells. Daily repeated ultrasound stimulation, which resembles the clinical schedule, substantially increases cell numbers, demonstrating that a physical stimulus (acoustic pulsed energy) can promote cell proliferation, which is a prerequisite for injury healing.

The athermal mechanisms have a considerable effect on therapeutic results (tissue regeneration), increasing permeability, diffusion of the cell membrane and intracellular calcium as well as changing the electric activity of the tissue $[18,21]$.

However, several parameters must be carefully controlled in order to minimize cell damage, including the acoustic pressure level, flow properties and temperature [22]. Furthermore, a wide range of ultrasound parameters have been tested by varying acoustic frequency, pressure, energy exposure time and duty cycle. Experimental systems and acoustic conditions have generally been designed to produce cavitation, which is believed to be responsible for bioeffects [23]. The destructive effect of ultrasound is likely to occur under the influence of high intensities, which suggests that cavitation is the physical mechanism responsible for cell alterations. Membrane alterations and the consequent destruction of several kinds of chicken embryo cells submitted to ultrasound irradiation have been observed [24].

According to Demir et al. [25] and Lowe et al. [26], ultrasound has demonstrated efficiency in the stimulation of fibroblasts, establishing that intensities from $0.1 \mathrm{~W} / \mathrm{cm}^{2}$ to $0.5 \mathrm{~W} / \mathrm{cm}^{2}$ accelerate

Table II. Significance values obtained from variance analysis of means of experiments by one-way ANOVA and Tukey's HSD post hoc test, for cells irradiated by ultrasound in pulsed mode at $20 \%$ (2:8 duty cycle)

\begin{tabular}{|lccc|}
\hline Time $[\mathrm{h}]$ & Control vs. $0.2 \mathrm{~W} / \mathrm{cm}^{2}$ & Control vs. $0.6 \mathrm{~W} / \mathrm{cm}^{2}$ & $0.2 \mathrm{~W} / \mathrm{cm}^{2} \mathrm{vs.} 0.6 \mathrm{~W} / \mathrm{cm}^{2}$ \\
\hline 24 & $0.01^{*}$ & $0.01^{*}$ & $0.01^{*}$ \\
\hline 48 & $0.01^{*}$ & $0.01^{*}$ & 0.08 \\
\hline 72 & $0.01^{*}$ & $0.01^{*}$ & 0.068 \\
\hline 96 & $0.001^{*}$ & $0.001^{*}$ & $0.001^{\star}$ \\
\hline
\end{tabular}

${ }^{*}$ For values with statistical significance 
the inflammatory phase of repair, suggesting that ultrasound intensities of about $0.5 \mathrm{~W} / \mathrm{cm}^{2}$ in pulsed mode and a frequency of $1 \mathrm{MHz}$ or $3 \mathrm{MHz}$ promote healing.

Marking with rhodamine-phalloidin allowed the analysis of alterations in the cell structures of a single cell. The data obtained from the groups that received ultrasonic irradiation indicate that intensities between $0.2 \mathrm{~W} / \mathrm{cm}^{2}$ and $0.6 \mathrm{~W} / \mathrm{cm}^{2}$ are beneficial to cells [27]. This corroborates the work of Oliveira et al. [28], which established that energy levels of $0.2-0.6 \mathrm{~W} / \mathrm{cm}^{2}$ of ultrasound were quite effective in stimulating fibroblasts and cell repair.

Dyson et al. [29] report that an increase in intensity tends to reduce the number of viable cells; cell death in the $1^{\text {st }} \mathrm{h}$ after irradiation suggests an alteration in the membrane of cultivated cells.

Thus, based on therapeutic advances resulting from technological progress in recent decades, ultrasound is a resource that has achieved good results as a healing therapy. In the inflammatory phase of tissue repair, an acceleration of the process is observed, increasing the release of growth factors through the degranulation of mastocytes, platelets and macrophages. In ultrasound therapy, the proliferation phase is begun early, reducing its duration, and is followed by the re-modelling phase. Hence, scar contraction is an important step that seems to accelerate the release of these growth factors stimulated by the ultrasound [11].

In conclusion, according to parameters used in the irradiation of cultivated fibroblasts, the pulse mode regime and the control of intensity are of fundamental importance for the optimal use of therapeutic ultrasound. Furthermore, low and medium intensities decreased cell damage, which establishes that acoustic pulsed energy induces the proliferation of fibroblast cells and provides a better knowledge of the cellular behaviour and a molecular basis for the clinical observation that ultrasound treatment of wounds promotes tissue repair.

\section{Acknowledgments}

We would like to thank Fundação de Amparo à Pesquisa do Estado de São Paulo - FAPESP, Universidade do Vale do Paraíba - UNIVAP, KLD ${ }^{\circledR}$ Biosistemas Equipamentos Eletrônicos Ltda - Brazil and Nelson Fuirini Junior for supporting this study.

\section{References}

1. Lai J, Pittelkow MR. Physiological effects of ultrasound mist on fibroblasts. Int J Dermatol 2007; 46: 587-93.

2. Tran TA, Roger S. Le Guennec JY, Tranquart F, Bouakaz A. Effect of ultrasound-activated microbubles on the cell electrophysiological properties. Ultrasound Med Biol 2007; 33: 158-63.

3. Dyson M. Mechanisms involved in therapeutic ultrasound. Physiotherapy 1987; 73: 116-20.
4. Young SR, Dyson M. Effect of therapeutic ultrasound on the breaking of full-thickness excised skin lesions. Ultrasonics 1990; 28: 170-80.

5. Carstensen EL, Gracewski S, Dalecki D. The search for cavitation in vivo. Ultrasound Med Biol 2000; 26: 1377-85.

6. Milowska K. Ultrasound mechanisms of action and application in sonodynamic therapy. Postepy Hig Med Dośw 2007; 61: 338-49.

7. O'Brien Jr WD. Ultrasound-biophysics mechanisms. Prog Biophys Mol Biol 2007; 93: 212-55.

8. Miller DL, Gies RA. The influence of ultrasound frequency and gas-body composition on the contrast agentmediated enhancement of vascular bioeffects in mouse intestine. Ultrasound Med Biol 2000; 26: 307-13.

9. Ziskin MC, Barnett SB. Ultrasound and the developing central nervous system. Ultrasound Med Biol 2001; 27: 875-6.

10. Shao ZY, Zhai BJ, Zhao CL, Hu K, Shen DM, Wu F. Cytotoxic effects and in vitro reversal of multidrug resistance by therapeutic ultrasound in human hepatocarcinoma cell line (HepG2). Ultrasonics 2008; 48: 297-302.

11. Gonçalves G, Parizotto NA. Fisiopatologia da regeneração cutânea: atuação da fisioterapia. Revista Brasileira de Fisioterapia 1998; 3: 5-13.

12. Warden SJ, Fuchs RK, Kessler CK, et al. Ultrasound produced by a cconventional therapeutic ultrasound unit accelerates fracture repair. Phys Ther 2006; 86: 1118-27.

13. Zhou S, Schmelz A, Seufferlein T, Li Y, Zhao J, Bachem MG. Molecular mechanisms of low intensity pulsed ultrasound in human skin fibroblasts. J Biol Chem 2004; 279: 54463-9.

14. Carvalho PT, Silva IS, Reis FA, et al. Histological study of tendon healing in malnorished Wistar rats treated with ultrasound therapy. Acta Cir Bras 2006; 21: 13-7.

15. Hawkins DH, Abrahamse $H$. The role of laser fluence in cell viability, proliferation and membrane integrity of wounded human skin fibroblasts following Helium-Neon laser irradiation. Lasers Surg Med 2006; 38: 74-83.

16. International Standard - ISO 10993-5, second edition199905-15. Biological evaluation of medical devices. Part 5: Tests for in vitro cytotoxicity.

17. Fotakis G, Timbrell JA. In vitro cytotoxicity assays: comparison of LDH, neutral red, MTT and protein assay in hepatoma cell lines following exposure to cadmium choride. Toxicol Lett 2006; 160: 171-7.

18. Hsieh YL. Effects of ultrasound and diclofenac phonophoresis on inflammatory pain relief: suppression of inducible nitric oxide synthase in arthritic rats. Phys Ther 2006; 86: 39-49.

19. Ter Haar G. Basic physics of therapeutic ultrasound. Physiotherapy 1987; 74: 110-3.

20. Kodama T, Tomita Y, Koshiyama K, Blomley MJ. Transfection effect of microbubbles on cells in superposed ultrasound waves and behavior of cavitation buble. Ultrasound Med Biol 2006; 32: 905-14.

21. Lirani-Galvão AP, Jorgetti V, Silva OL. Comparative study of how low-level laser therapy and low-intensity pulsed ultrasound affect bone repair in rats. Photomed Laser Surg 2006; 24: 735-40.

22. Hultstrom J, Manneberg O, Dopf K, Hertz HM, Brismar H, Wiklund M. Proliferation and viability of adherent cells manipulated by standing-wave ultrasound in a microfluidic chip. Ultrasound Med Biol 2007; 33: 145-51.

23. Hallow DM, Mahajan AD, McCutchen TE, Prausnitz MR. Measurement and correlation of acoustic cavitation with cellular bioeffects. Ultrasound Med Biol 2006; 32: 1111-22.

24. Chapman IV, Macnally NA, Tucker S. Ultrasound induced changes in the rates of influx and efflux of potassium ions in rat thymocytes in vitro. Br J Radiol 1979; 47: 411-5. 
25. Demir H, Yaray S, Kirnap M, Yaray K. Comparison of the effects of laser and ultrasound treatments on experimental wound healing in rats. J Rehabil Res Develop 2004; 41: 721-8.

26. Lowe AS, Walker MD, Cowan R, Baxter GD. Therapeutic ultrasound and wound closure: lack of healing effect on $x$-ray irradiated wound in murine skin. Arch Phys Med Rehabil 2001; 82: 1507-11.

27. Pires-Oliveira DA, Oliveira RF, Magini M, Zangaro RA Soares CP. Assessment of cytoskeleton and endoplasmic reticulum of fibroblast cells subjected to low-level laser therapy and low-intensity pulsed ultrasound. Photomed Laser Surg 2009; 27: 461-6.

28. Oliveira RF, Pires-Oliveira DA, Monteiro W, Zangaro RA, Magini M, Soares CP. Comparison between the effect of low-level laser therapy and low-intensity pulsed ultrasonic irradiation in vitro. Photomed Laser Surg 2008; 26: 6-9.

29. Dyson M, Pond JB, Woodward J, Broadbent J. The production of blood cell stasis and endothelial cell damage in the blood vessels of chick embryos treated with ultra-sound in a stationary wave field. Ultrasound Med Biol 1974; 1: 133-48. 